Borneo Journal of Phamascientech, Vol. 04, No. 01, April Tahun 2020

ISSN-Print. 2541-3651

ISSN-Online. 2548 - 3897

Research Article

\title{
SKRINING FITOKIMIA DAN UJI AKTIVITAS ANTIBAKTERI EKSTRAK ETANOL 70\% BIJI KALANGKALA (Litsea angulata Bl.) TERHADAP BAKTERI PENYEBAB JERAWATPropionibacterium acnes
}

\section{PHYTOCHEMICAL SCREENING AND ANTIBACTERIAL ACTIVITIES OF 70\% ETHANOL EXTRACTS OF KALANGKALA SEEDS (Litsea angulata Bl.) ON BACTERIA CAUSES ACNEPropionibacterium acnes}

\author{
Hafiz Ramadhan*, Muhammad Arsyad, Putri Indah Sayakti \\ Sekolah Tinggi Ilmu Kesehatan Borneo Lestari \\ *hafizramadhan14@gmail.com
}

\begin{abstract}
ABSTRAK
Acne vulgaris atau jerawat merupakan suatu penyakit inflamasi kronik pada unit polisebaseus yang sering terjadi khususnya pada remaja dan dewasa yang salah satunya disebabkan oleh bakteri Propionibacterium acnes.Bahan alam yang punya potensi sebagai antibakteri adalah Kalangkala (Litsea angulata Bl.) yang mana sebagian masyarakat Kalimantan Selatan menggunakan bijinya untuk mengobati bisul.Penelitian ini bertujuan untuk mengetahui kandungan metabolit sekunder ekstrak etanol $70 \%$ biji Kalangkala dan aktivitasnya sebagai antibakteri terhadap P.acnes.Uji skrining fitokimia meliputi flavonoid, alkaloid, saponin, steroid-terpenoid dan tanin. Metode uji aktivitas antibakteri dengan metode difusi sumuran menggunakan konsentrasi ekstrak 100\%; 50\%; 25\%; 12,5\%; 6,25\%; dan 3,125\%. Hasil penelitian menunjukkan ekstrak etanol $70 \%$ biji Kalangkala mengandung senyawa flavonoid, alkaloid, saponin dan tanin. Aktivitas antibakteri ekstrak etanol $70 \%$ biji Kalangkala (Litsea angulata $\mathrm{Bl}$.) terhadap bakteri Propionibacterium acnes dengan metode difusi sumuran didapatkan MIC yaitu 25\% dengan rata-rata diameter zona hambat sebesar $8,667 \mathrm{~mm}$ yang termasuk kategori sedang sebagai zat antibakteri.
\end{abstract}

Kata kunci :Biji Kalangkala (Litsea angulata Bl.), Skrining Fitokimia, Antibakteri, Propionibacterium acnes. 
Borneo Journal of Phamascientech, Vol. 04, No. 01, April Tahun 2020

ISSN-Print. 2541-3651

ISSN-Online. 2548 - 3897

Research Article

\begin{abstract}
Acne vulgaris or acne is a chronic inflammatory disease in the polysebaseus unit that often occurs especially in teenagers and adults, one of which is caused by the bacterium Propionibacterium acnes. Natural material that has the potential as an antibacterial is Kalangkala (Litsea angulata Bl.), where some people in South Kalimantan use the seeds to treat boils. This research purposes to determine the content of secondary metabolites of $70 \%$ ethanol extract of Kalangkala seeds andtheir activities as antibacterial againts P.acnes. The phytochemical screening test includes flavonoids, alkaloids, saponins, steroids-terpenoids and tannins. The method of testing the antibacterial activity with the well diffusion method using extract concentration 100\%; 50\%; 25\%; 12.5\%; 6.25\%; and 3.125\%. The results showed $70 \%$ ethanol extract of Kalangkala seeds containing flavonoids, alkaloids, saponins and tannins. The antibacterial activity of $70 \%$ ethanol extract of Kalangkala seeds againts Propionibacterium acnes bacteria with well diffusion method was obtained by MIC that is $25 \%$ with an average inhibition zone diameter of 8,667 mm which included the moderate category as an antibacterial agent.
\end{abstract}

Keywords :Kalangkala Seeds (Litsea angulata Bl.), Phytochemical Screening, Antibacterial, Propionibacterium acnes.

\title{
PENDAHULUAN
}

Acne vulgaris atau jerawat merupakan suatu penyakit inflamasi kronik pada unit polisebaseus yang ditandai dengan komedo, papul, pustul, nodul, dan kista.Salah satu mekanisme terjadinya jerawat adalah bakteri Propionibacterium acnes.Pengobatanjerawat menggunakan golongan antibiotik topikal seperti Eritromisin dan Klindamisin, akan tetapi penggunaan antibiotik dapat menyebabkan resistensi, oleh sebab itu perlu dicari alternatif pengobatan dengan bahan alam(Hartiniet al.,2012; Afriyanti, 2015).

Salah satu bahan alam yang punya potensi sebagai antibakteri adalah Kalangkala (Litsea angulata B1.).Sebagian masyarakat KalimantanSelatan menggunakan tumbuhan ini terutama biji buahnya secara tradisional untuk mengobati bisul (Mustikasari \& Ariyani, 2010; 
Borneo Journal of Phamascientech, Vol. 04, No. 01, April Tahun 2020

ISSN-Print. 2541-3651

ISSN-Online. 2548 - 3897

Research Article

Kuspradiniet al.,2018). Aktifitas

menggunakan metode difusi sumuran.

tersebut kemungkinan dihasilkan karena biji Kalangkala (L. angulate B1.) mengandung beberapa metabolit sekunder yang memiliki aktivitas antibakteri seperti alkaloid dan tannin (Mustikasari \& Ariyani, 2010).Pada penelitian Sari (2018) menyebutkan bahwa biji Kalangkala juga positif mengandung flavonoid, tannin, dan fenol.

Pada penelitian tahun 2019 oleh Kuspradini et al. yang melakukan ekstraksi kulit batang, cabang, dan daun Kalangkala menunjukkansemuaekstrakdapat menghambatpertumbuhan bakteri Streptococcus mutans dan Staphylococcusaureus dengan nilai MIC 156,25 ppm.Berdasarkan latar belakang tersebut, dilakukan penelitian dengan memanfaatkan kandungan metabolit sekunder hasil skrining fitokimia biji Kalangkala (Litsea angulate B1.) yang diekstraksi menggunakan metode maserasi dengan pelarut etanol $70 \%$.Kemudian ekstrak diujikan aktivitasnya terhadap $P$. acnes

\section{METODOLOGI}

\section{Alat dan Bahan}

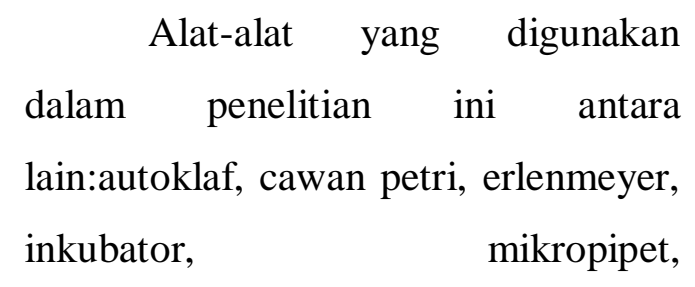
timbangan,rotaryevaporator, waterbath

Bahan-bahan yang digunakan dalam penelitian ini adalah: ekstrak etanol 70\% biji Kalangkala, aquadest, media MHA (Mueller Hinton Agar), Nutrient Agar, serbuk Mg, $\mathrm{HCl}$ pekat, pereaksi Mayer, Wagner, Dragendorff,pereaksi

LiebermannBurchard biakan bakteri Propionibacterium acnes, dan cakram uji antibiotik klindamisin.

\section{Prosedur Penelitian}

Ekstraksi Biji Kalangkala

Serbuk biji Kalangkala diekstraksi dengan etanol $70 \%$. Ekstraksi dilakukan selama 3 x 24 jam sambil diaduk. Hasil maserasi disaring dan diuapkan pelarutnya denganrotaryevaporator dan 
Borneo Journal of Phamascientech, Vol. 04, No. 01, April Tahun 2020

ISSN-Print. 2541-3651

ISSN-Online. 2548 - 3897

Research Article

waterbath pada suhu $60^{\circ} \mathrm{C}$ (Akmal et al., 2016).

\section{Uji Skrining Fitokimia}

\section{Uji Flavonoid}

Sampel sebanyak $\quad 0,5 \mathrm{~g}$ ditambahkan5 $\mathrm{mL}$ air, didihkan kurang lebih 5 menit lalu disaring. Filtrat sebanyak $2 \mathrm{~mL}$ ditambahkan 0,05 mg serbuk $\mathrm{Mg}$ dan $1 \mathrm{~mL} \mathrm{HCl}$ pekat, kemudian dikocok hingga homogen. (Marina et al., 2015).

\section{Uji Alkaloid}

Sampel 0,5 g ditambahkan $5 \mathrm{~mL}$ $\mathrm{HCl}$, kemudian dibagi ke dalam 3 tabung,pada tabung 1 ditambah pereaksi Mayer, tabung 2 ditambah pereaksi Dragendorff, tabung 3 ditambah pereaksi Wagner. (Pratima \& Shaille, 2012).

\section{Uji Saponin}

Sampel sebanyak 0,5 g, ditambahkan $5 \mathrm{~mL}$ air panas dikocok kuat selama kurang lebih 10 detik. Apabila terbentuk busa stabil selama kurang lebih 10 menitdan setelahditambahkan 1 tetes $\mathrm{HCl} 2 \mathrm{~N}$, busa tersebut tidak hilang (Marina et al., 2015).

\section{Uji Steroid-Triterpenoid}

Sampel

sebanyak0,5g,ditambahkan

dietil eter. Sampel yang larut dalam dietil eter ditambahkan pereaksi LiebermannBurchard (Yuda et al., 2017).

\section{Uji Tannin}

Sampel sebanyak 0,5g ditambahkan larutan gelatin 1\%(Yuda et al., 2017).

\section{PeremajaanPembuatan Suspensi Propionibacterium acnes}

Bakteri uji ditumbuhkan pada medium Nutrient Agar (NA) dengan cara menggoreskan bakteri dari biakan murni pada media lalu diinkubasi pada suhu $37^{0} \mathrm{C}$ selama 2 hari (48 jam).Biakan $P$. acnes pada media NA diambil 1 ose dan ditambahkan 0,5 mL larutan garam fisiologis $(\mathrm{NaCl}) 0,9 \%$ steril, lalu diinkubasi selama 24 jam pada suhu $\quad 37^{\circ} \mathrm{C}$, kemudian dibandingkan kekeruhannya dengan larutan standar Mc Farland 0,5 (1,5×108 CFU/ml) (Aziz, 2010). 
Borneo Journal of Phamascientech, Vol. 04, No. 01, April Tahun 2020

ISSN-Print. 2541-3651

ISSN-Online. 2548 - 3897

Research Article

Uji Aktivitas Antibakteri Dengan Metode Sumuran

Cawan petri yang sudah diinokulasi suspensi bakteri $P$. acnes dimasukan variasi konsentrasi $(100 \%$; $50 \%$; $25 \%$; $12,5 \%$; $6,25 \%$; dan $3,125 \%)$ ekstrak etonol $70 \%$ biji Kalangkala sebanyak $20 \mu \mathrm{L}$ ke dalam setiap lubang sumuran pada media MHA. Sebagai kontrol positif disk antibiotik klindamisin dan kontrol negatif $\mathrm{Na} \mathrm{CMC}$ 0,5\%. Letakkan kultur tersebut pada suhu $2-8^{\circ} \mathrm{C}$ selama 14-18 jam. Setelah itu diinkubasi pada suhu $37^{\circ} \mathrm{C}$. Selanjutnya potensi aktivitas antibakteri diamati setelah 24 jam inkubasi dengan melihat zona hambatnya (Ramadhan, 2017; Fitriyanti et al., 2020).

\section{Pengolahan dan Analisis Data}

Data hasil yang didapat dari pengujian metode difusi sumuran berupa diameter zonahambatdianalisisdenganmengguna kanSPSS.

\section{HASIL DAN PEMBAHASAN}

Ekstraksi Biji Kalangkala (Litsea angulata $\mathrm{Bl}$.)

Ekstraksi biji Kalangkala (Litsea angulata $\mathrm{B1}$.) dilakukan dengan metode dingin yaitu maserasi menggunakan pelarut etanol $70 \%$. Metode maserasi dipilih karena prosesnya mudah dan tidak menggunakan suhu tinggi yang mungkin dapat merusak senyawasenyawa kimia yang memiliki aktivitas tertentu dalam simplisia (Al Ridho, 2014). Penggunaan pelarut etanol $70 \%$ pada proses maserasi karena sifatnya yang mampu melarutkan hampir semua zat- zat baik yang bersifat polar, semipolar, dan nonpolar (Aminah et al., 2016).

\section{Skrining Fitokimia Ekstrak Etanol} 70\% Biji Kalangkala (Litsea angulata $\mathrm{Bl}$.)

Hasil skrining fitokimia ekstrak etanol $70 \%$ biji Kalangkala (Litsea angulata $\mathrm{B} 1$.) positif mengandung metabolit sekunder golongan alkaloid, flavonoid, saponin, dan tanin yang kemungkinan berperan sebagai 
Borneo Journal of Phamascientech, Vol. 04, No. 01, April Tahun 2020

ISSN-Print. 2541-3651

ISSN-Online. 2548 - 3897

Research Article

antibakteri sepertiyang ditunjukkan dibanding hasil maserasi pada tabel I. Hasil tersebut menggunakan pelarut metanol pada menunjukkan maserasi biji kalangkala dengan etanol $70 \%$ dapat menyari penelitianMustikasari $\&$ lebih banyak metabolit sekunder Ariyani(2010)yang hanya mengandung golongan alkaloid dan tannin.

Tabel I. Hasil Skrining Fitokimia Ekstrak Etanol 70\% Biji Kalangkala (Litsea angulata Bl.)

\begin{tabular}{|c|c|c|c|c|}
\hline No & Jenis Uji & Pereaksi & Hasil & Keterangan \\
\hline \multirow{3}{*}{1.} & \multirow{3}{*}{ Alkaloid } & - HCl\&Dragendorff & $(+)$ & $\begin{array}{c}\text { Terdapat endapan kuning } \\
\text { kejinggaan }\end{array}$ \\
\hline & & - HCl\& Mayer & $(-)$ & Tidak ada endapan putih \\
\hline & & - HCl\&Wagner & $(+)$ & $\begin{array}{l}\text { Terdapat endapan merah } \\
\text { kecoklatan }\end{array}$ \\
\hline 2. & Flavonoid & $\begin{array}{l}\text { - HCl Pekat } \\
\text { - Magnesium }\end{array}$ & $(+)$ & $\begin{array}{c}\text { Terbentuk warna kuning sampai } \\
\text { jingga }\end{array}$ \\
\hline 3. & Saponin & $\begin{array}{l}\text { - Aquades } \\
\text { - } \mathrm{HCl} 2 \mathrm{~N}\end{array}$ & $(+)$ & Terdapat busa yang stabil \\
\hline 4. & $\begin{array}{l}\text { Steroid- } \\
\text { triterpenoid }\end{array}$ & $\begin{array}{c}\text { - Asam asetat anhidrat } \\
-\mathrm{H}_{2} \mathrm{SO}_{4} \\
\end{array}$ & $(-)$ & $\begin{array}{c}\text { Tidak terbentuknya warna hijau } \\
\text { atau biru }\end{array}$ \\
\hline 5. & Tannin & - Gelatin 1\% & $(+)$ & Terdapat endapan putih \\
\hline
\end{tabular}

\section{Uji Aktivitas Antibakteri Ekstrak}

Etanol 70\% Biji Kalangkala (Litsea

angulata Bl.)Terhadap Bakteri

P.acnes Dengan Metode Sumuran

Pada pengujian aktivitas

antibakteri digunakan 6 seri konsentrasiyaitu 100\%; 50\%; 25\%;

$12,5 \%$; 6,25\%; dan 3,125\% dengan

klindamisin sebagai kontrol positif dan

Na-CMC sebagai kontrol negatif.

Metode pengujian dilakukan dengan difusi sumuran. Metode ini dipilih karena metode inimampu memperoleh diameter zonahambat yang lebih besar dibandingkan denganmetode disk diffusion. Hal ini diakibatkan karena pada metode sumuran terjadi proses osmolaritas yang lebih tinggi dari konsentrasi ekstrak ke dalam media dibanding metode disk diffusion. Pada metode sumuran, setiap lubangnya diisi dengan konsentrasi ekstrak 
Borneo Journal of Phamascientech, Vol. 04, No. 01, April Tahun 2020

ISSN-Print. 2541-3651

ISSN-Online. 2548 - 3897

Research Article

sehinggaosmolaritas terjadi lebih 70\% biji Kalangkalaterhadap menyeluruh dan lebih homogen, serta P.acnesmenggunakan metode sumuran konsentrasi ekstrak yang dihasilkan dapat dilihat pada tabel II dan gambar lebih tinggidan lebih kuat untuk 1. menghambat pertumbuhan bakteri (Haryati et al., 2017). Hasil pengujian aktivitas antibakteri dari ekstrak etanol

Tabel II. Rata-Rata Diameter Zona Hambat Dari Ekstrak Etanol 70\% Biji Kalangkala Terhadap Pertumbuhan BakteriP.acnes Dengan Metode Sumuran.

\begin{tabular}{|c|c|c|c|c|c|}
\hline \multirow{2}{*}{ Konsentrasi(\%) } & \multicolumn{3}{|c|}{ Diameter Zona Hambat (mm) } & \multirow{2}{*}{$\begin{array}{c}\text { Rata-Rata } \pm \\
\mathbf{S D}(\mathbf{m m})\end{array}$} & \multirow{2}{*}{ Kategori } \\
\hline & $\mathbf{1}$ & 2 & 3 & & \\
\hline 100 & 12 & 13 & 13 & $12,67 \pm 0,58$ & Kuat \\
\hline 50 & 10 & 12 & 11 & $11 \pm 1$ & Kuat \\
\hline 12,5 & 8 & 9 & 9 & $8,67 \pm 0,58$ & Sedang \\
\hline 6,25 & - & - & - & - & - \\
\hline 3,125 & - & - & - & - & - \\
\hline Klindamisin $0,1 \%$ & 28 & 31 & 29 & $29,33 \pm 1,53$ & Sangat Kuat \\
\hline $\mathrm{Na}-\mathrm{CMC} 0,5 \%$ & - & - & - & - & - \\
\hline
\end{tabular}

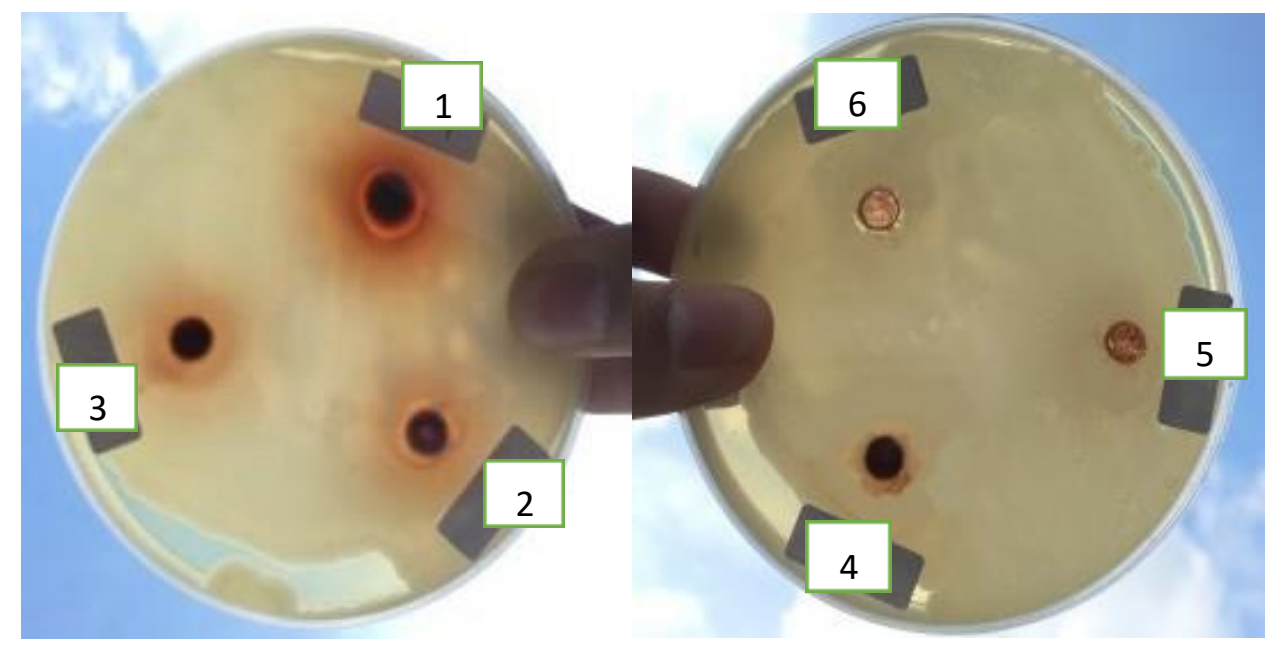

(a)

(b)

Gambar 1. Hasil Uji Aktivitas Antibakteri Ekstrak Etanol 70\% Biji

KalangkalaterhadapBakteriP. acnes Dengan Metode Sumuran (a) Konsentrasi : 1) 100\%; 2) $50 \%$; 3) $25 \%$ dan (b) Konsentrasi : 4) $12,5 \%$; 5) 6,25\% ; 6) 3,125\%. 
Borneo Journal of Phamascientech, Vol. 04, No. 01, April Tahun 2020

ISSN-Print. 2541-3651

ISSN-Online. 2548 - 3897

Research Article

Berdasarkan penelitian yang telah dilakukan, dapat dikatakan bahwa MIC (Minimum Inhibitory Concentration) dari ekstrak etanol $70 \%$ bijiKalangkala yaitu $25 \%$ yang termasuk dalam kategori sedang, sedangkan konsentrasi $50 \%$ dan $100 \%$ termasuk dalam kategori kuat. Hasil tersebut menunjukkan bahwa ekstrak etanol $70 \%$ biji Kalangkala memiliki potensi sebagai antibakteri terhadap P.acnes tetapi tidak lebih poten dibandingkan dengan kontrol positif klindamisin $0,1 \%$ yang memiliki daya aktivitas antibakteri yang sangat kuat.

Zona hambat yang dihasilkan ekstrak etanol $70 \%$ biji Kalangkala berhubungan dengan hasil uji skrining fitokimia yang menunjukkan kandungan senyawa flavonoid, alkaloid, saponin, dan tannin yang berperan dalam menghasilkan aktivitas antibakteri. Flavonoid dan tanin merupakan senyawa golongan fenolik yang memiliki mekanisme antibakteri dengan mengubah permeabilitas membran sitoplasma, sehingga menyebabkankebocoransel.

Golongan senyawa ini juga mendenaturasi dan menginaktifkan protei/enzim.Sedangkanmekanismea lkaloiddengan mengganggu komponen peptidoglikan, sehingga lapisan dinding sel tidak terbentuk secara utuh dan menyebabkan kematian sel (Hafsari et al, 2016).

Senyawa saponin juga teridentifikasipositif terkandung dalam ekstrak etanol $70 \%$ biji Kalangkala.Saponin bekerja efektif pada bakteri Gram positif.Sifat antibakteri yang dimiliki saponin disebabkan oleh mekanisme kerjanyayang dapat meningkatkan permeabilitas membran sel sehingga menjadi tidak stabil dan terjadi hemolisis sel (Rahman et al,2017).

Hasil analisis data menggunakan SPSS dinyatakan homogen tetapi tidak terdistribusi normal.Hasil uji non parametrik KruskalWallismenunjukkan sig sebesar $0.002(\mathrm{p}<0.05)$. Berdasarkan nilai tersebut dapat disimpulkan bahwa 
Borneo Journal of Phamascientech, Vol. 04, No. 01, April Tahun 2020

ISSN-Print. 2541-3651

ISSN-Online. 2548 - 3897

Research Article

terdapat perbedaan signifikan terhadap masing-masing kelompok.Hasilanalisis

menggunakan uji Mann-Whitney juga menunjukkan konsentrasi $100 \%, 50 \%, 25 \%, 12,5 \%, 6,25 \%$, dan $3,125 \%$ memiliki nilai signifikansi $>0.05$,yang dapat disimpulkan bahwa tidak terdapat perbedaan hasil zona hambat yang signifikan.

\section{KESIMPULAN}

Kandunganmetabolit sekunder dari ekstrak etanol $70 \%$ biji Kalangkala (Litsea angulata B1.) adalah flavonoid, alkaloid, saponin, dantanin yang berperan dalam menghasilkanaktivitas antibakteri terhadap bakteri Propionibacterium acnes dengan MIC 25\% memiliki rata-rata diameter zona hambat 8,67 mm yang termasuk kategori sedang sebagai zat antibakteri.

\section{DAFTAR PUSTAKA}

Afriyanti, R.N. 2015. Akne Vulgaris Pada Remaja.Jurnal Majority. 4(6): 102-109.
Akmal, R., Kuswanto., Fahrunnisa, S., Rahmi, R. A., Bayanil, N. E. P., Nurliani, A. 2016.Efek Spermisida Ekstrak Metanol Biji Buah Kalangkala (Litsea angulata) terhadap Spermatozoa Mencit (Mus musculus). Journal of Agromedicine and Medical Sciences. 2(2): 18-23.

Al Ridho, E. 2014. Uji Aktivitas Antioksidan Buah Lakum (Cayratia trifolia) Dengan Metode DPPH (2,2-diphenyl-1picrylhidrazyl).Jurnal Mahasiswa Farmasi Fakultas Kedokteran UNTAN.

Aminah., Maryam, S., Baits, M., Kalsum, U. 2016. Perbandingan Aktivitas Antioksidan Ekstrak Etanol Daun Sirsak (Annona muricata L.) Berdasarkan Tempat Tumbuh Dengan Metode Peredaman DPPH.Jurnal Fitofarmaka Indonesia. 3(1):146150.

Aziz, S., 2010.Uji Aktivitas Antibakteri Ekstrak Etanol Daun dan Umbi BakungPutih (Crinum asiaticum L.) Terhadap Bakteri Penyebab Jerawat. Skripsi.Program Studi Farmasi. Fakultas Kedokteran dan Ilmu Kesehatan.UIN Syarif Hidayatullah. Jakarta.

Fitriyanti, Norhavid, M.F.R., Ramadhan, H. 2020.Uji Daya Hambat Ekstrak Etanol 70\% Biji 
Borneo Journal of Phamascientech, Vol. 04, No. 01, April Tahun 2020

ISSN-Print. 2541-3651

ISSN-Online. 2548 - 3897

Research Article

Pepaya (Carica papaya L.) Terhadap Bakteri

Propionibacterium acnes

Penyebab

Jerawat.Pharmacoscript.

3(2):143-149.

Hafsari, A.R., Cahyanto, T., Sujarwo,

T., Lestari, R. I. 2015. Uji Aktivitas Antibakteri Ekstrak Daun Beluntas (Pluchea indica (L.) LESS.)Terhadap Propionibacterium acnes Penyebab Jerawat.Jurnal Istek. 9(1):146-150.

Hartini, S., Fahrezi, A.G., Supomo, J. 2012.10 Cara Paling Jitu Mengatasi Jerawat dan Komedo.Babarsari Printika, Yogyakarta.

Haryati, S.D., Darmawati, S., Wilson, W. 2017. Perbandingan Efek Ekstrak Buah Alpukat (Persea americanaMill) Terhadap Pertumbuhan Bakteri Pseudomonas aeruginosa Dengan MetodeDiskDan

Sumuran.Prosiding Seminar Nasional Publikasi Hasil-Hasil Penelitian dan Pengabdian Masyarakat, Universitas Muhammadiyah Semarang. 348352.

Kuspradini, H., Putri, A.S., Diana, R. 2018. Potensi Tumbuhan Genus Litsea. Mulawarman University Press. Samarinda.
Kuspradini, H., Wulandari, I., Putri, A.S., Tiya, S.Y., Kusuma, I.W.2019. Phytochemical, Antioxidant and Antimicrobial Properties of Litsea angulata Extracts.

F1000Research. 7 (1839): 1-11.

Marina, E., Manurung, H., Nugroho, R.A. 2015. Uji Fitokimia dan Antibakteri Ekstrak Etanol Daun Balangla (Litseacubeba(Lour.)Pers.)Terhad apBakteriStapylococcus aureus dan Escherichia coli.Prosiding Seminar Sains dan Teknologi FMIPA Unmul, UniversitasMulawarman, Samarinda. 1(1): 1-9.

Mustikasari, K.\& Ariyani, D. 2010. Skrining Fitokimia Ekstrak Metanol Biji Kalangkala (Litsea angulata). Jurnal Ilmiah Berkala Sains dan Terapan Kimia. 4(2): 131-136.

Pratima, A.N. \& Shailee, T. 2012.Ethosomes: A NovelToolforTransdermal DrugDelivery. International Journal of Research in Pharmacy dan Science. 2(1):1-20.

Rahman, F.A., Haniastuti, T., Utami, T.W.2017.Skrining Fitokimia Dan Aktivitas Antibakteri Ekstrak Etanol Daun Sirsak (Annona muricata L.) Pada Streptococcus mutans ATCC 35668.Majalah Kedokteran Gigi Indonesia. 3(1): 
Borneo Journal of Phamascientech, Vol. 04, No. 01, April Tahun 2020

ISSN-Print. 2541-3651

ISSN-Online. 2548 - 3897

Research Article

$1-7$.

Ramadhan, H. 2017. Isolasi Actinomycetes Penghasil Antibiotik Terhadap Escherichiacolidan

Staphylococcus aureus Dari Tanah Sawah. Prosiding Seminar Nasional dan Presentasi Ilmiah Perkembangan Terapi Obat Herbal Pada Penyakit Degeneratif, STIKES Borneo Lestari Banjarbaru. 1(1): 50-64.

Sari, E.A. 2018.Studi Farmakognostik Simplisia Buah dan Biji Buah Kalangkala (Litsea angulata) Asal Barabai Hulu Sungai Tengah Kalimantan Selatan.Skripsi. Program Studi S1 Farmasi, STIKES Borneo Lestari Banjarbaru.

Yuda, P.E.S.K., Cahyaningsih, E., Winariyanthi, $\quad$ N.L.P.Y. 2017.Skrining Fitokimia dan Analisis Kromatografi Lapis Tipis Ekstrak Tanaman Patikan Kebo (Euphorbia hirta L.).Medicamento. 3(2): 61-70. 